\title{
Control of c-myc mRNA half-life in vitro by a protein capable of binding to a coding region stability determinant
}

\author{
Philip L. Bernstein, David J. Herrick, Rebecca D. Prokipcak, and Jeffrey Ross \\ McArdle Laboratory for Cancer Research, University of Wisconsin, Madison, Wisconsin 53706 USA
}

\begin{abstract}
Polysome-associated c-myc mRNA is degraded relatively rapidly in cells and in an in vitro mRNA decay system containing extracts from cultured mammalian cells. Using this system, a competition/screening assay was devised to search for factors that bind to specific regions of polysome-associated c-myc mRNA and thereby alter its half-life. mRNA stability was first assayed in reactions containing exogenous competitor RNAs corresponding to portions of $c-m y c$ mRNA itself. The addition of a 182-nucleotide sense strand fragment from the carboxy-terminal portion of the c-myc-coding region destabilized c-myc mRNA by at least eightfold. This RNA fragment had no effect on the stability of other mRNAs tested. Moreover, c-myc mRNA was not destabilized in reactions containing unrelated competitor RNAs or sense strand RNA from the c-myc $5^{\prime}$ region. Polysome-associated globin mRNA containing the c-myc-coding region segment in-frame was also destabilized in vitro by the 182-nucleotide RNA. As determined by UV-cross-linking experiments, the 182-nucleotide RNA fragment was recognized by and bound to an $\sim 75-k D$ polysome-associated protein. On the basis of these data plus Northern blotting analyses of c-myc mRNA decay products, we suggest that the $\sim 75-\mathrm{kD}$ protein is normally bound to a c-myc-coding region determinant and protects that region of the mRNA from endonuclease attack. Possible links between the protective protein, translation, ribosome pausing, and c-myc mRNA turnover are discussed.
\end{abstract}

[Key Words: c-myc mRNA; stability; ribonucleoprotcin; polyribosomes]

Received December 20, 1991; revised version accepted February 6, 1992.

Three observations indicate the extent to which mRNA stability influences gene expression, especially in cells of higher organisms (Marzluff and Pandey 1988; Cleveland and Yen 1989; Peltz et al. 1991). First, although the steady-state level of any mRNA reflects its synthesis and decay rates, the half-lives of many mRNAs seem to be the major determinants of their abundance. That is, mRNA abundance often correlates more closely with how long the mRNA persists in the cytoplasm than with how rapidly it is synthesized. Second, the half-life of a mRNA sets the time required to reach a new steady state following a change in transcription rate. The shorter the half-life, the sooner the new steady state is reached (Hargrove and Schmidt 1989|. Thus, a fivefold increase in the transcription of a given gene will eventually yield a fivefold increase in the abundance of the mRNA; however, a labile mRNA will reach the new steady state faster than a stable mRNA, illustrating a poorly appreciated but important link between mRNA stability and transcription. Third, as cells divide and differentiate, they modify the half-lives of specific mRNAs. For example, histone mRNA is approximately fourfold less stable in $G_{2}$ than in mid-S-phase of the cell cycle (Marzluff and Pandey 1989; Harris et al. 1991), whereas c-myc mRNA is stabilized four- to sixfold in response to growth factors and translational inhibitors (Kindy et al. 1986; Brewer and Ross 1989).

The c-myc mRNA half-life can increase or decrease, depending on the extracellular environment. Such fluctuations probably reflect the actions of different cytoplasmic regulatory factors that become activated or repressed in response to specific environmental signals. Each factor, in turn, probably recognizes distinct mRNA stability determinants, consistent with the observation that separate regions within the mRNA molecule influence its half-life. One stability determinant is located within the $3^{\prime}$-untranslated region (3'-UTR), and another in the coding region (Lachman et al. 1986; Jones and Cole 1987; Bonnieu et al. 1988, 1990; Wisdom and Lee 1990, 1991; Laird-Offringa et al. 1991; this paper). Other mRNAs, including c-fos, also contain at least two distinct regions that influence their half-lives (Rahmsdorf et al. 1987; Shyu et al. 1989, 1990). If the overall half-life of c-myc mRNA is determined by two or more independently functioning, structurally unique sequence elements, then each element might interact with different trans-acting regulatory factors. If so, a number of questions arise. Is each regulatory factor activated only under specific circumstances, for example, during the transition from quiescence to growth, during a single phase of 
cell differentiation, or following neoplastic transformation (Schuler and Cole 1988)? How does each factor interact with each region of the mRNA? What regulates the regulators?

We and others are exploiting in vitro assays to identify factors that regulate cytoplasmic mRNA stability and to determine whether these factors interact with specific regions of the mRNAs that they affect. A constitutively expressed cytosolic factor destabilizes c-myc and, perhaps, also c-myb mRNA. Inactivation of this destabilizer might account for the two- to fourfold accumulation of c-myc mRNA in cycloheximide-treated cells (Brewer and Ross 1989/. Two proteins of 37 and $40 \mathrm{kD}$ bind to AU-rich sequences located in the 3'-UTR of c-myc and other unstable mRNAs and accelerate c-myc mRNA decay in vitro (Brewer 1991).

Three considerations prompted us to exploit an in vitro mRNA decay system to search for additional regulatory factors that interact with $\mathrm{c}-m y c$ mRNA and change its half-life. First, it is important to understand as completely as possible the link between mRNA turnover and gene expression. To do so, it seems essential to characterize in detail how the stability of at least one mRNA is regulated, including a complete description of its degradation pathways, the mRNases that degrade the moleculc, and the factors that regulate its half-life. Second, c-myc mRNA provides an excellent subject for further study, because some details concerning its decay pathway are already known. Third, cell-free systems have been used to analyze mRNA half-lives and to identify regulatory factors. For example, c-myc mRNA is at least 20 -fold less stable than $\gamma$-globin and glyceraldehyde- 3 phosphate dehydrogenase (GAPDH) mRNAs, both in cells and in vitro (Ross and Kobs 1986; Brewer and Ross 1988; J. Ross and G. Brewer, unpubl.). For the experiments described here, polysomes containing c-myc mRNA were isolated from a human erythroleukemia cell line and were incubated in a cell-free mRNA decay system. Reactions were supplemented with exogenous sense or antisense competitor RNA fragments corresponding to different portions of $\mathrm{c}-m y c$ mRNA. If a regulatory factor were bound to a specific region of the mRNA, the factor might be titrated away by a competitor homologous to that region, thereby altering the mRNA half-life.

We find that one sense strand competitor fragment, containing the 182 carboxy-terminal-coding nucleotides, induces at least an eightfold destabilization of $c-m y c$ mRNA. Gel-shift and UV-cross-linking experiments reveal $a \sim 75-\mathrm{kD}$ protein that interacts with this RNA fragment. The protein sediments along with polysomes but is solubilized by exposing the polysomes to high salt. Northern blotting analyses suggest that the protein protects c-myc mRNA from endonucleolytic cleavage within the 182-nucleotide region, which we term the coding region determinant. In cell-free reactions, this protein also appears to protect a chimeric mRNA containing the c-myc-coding region determinant embedded within the translated region of human $\beta$-globin mRNA. A model is presented to suggest how the $\sim 75-\mathrm{kD}$ protein might interact with the coding region determinant and how it might influence c-myc mRNA stability under specific conditions.

\section{Results}

Destabilization of $c$-myc $m R N A$ in vitro by competition with sense strand RNA fragments from the carboxy-terminal-coding region

$\mathrm{c}-\mathrm{myc}$ mRNA is unstable in vitro in reactions containing polysomes, which serve as a source of endogenous mRNA substrate and degradation enzymes (Ross and Kobs 1986; Brewer and Ross 1988). The short in vitro half-life reflects $c-m y c$ mRNA lability in intact cells (Dani et al. 1984). To determine whether the polysomes contain RNA-binding proteins that influence c-myc mRNA turnover, various competitor RNAs were added to cell-free reactions. If a competitor sequestered a regulatory factor, the stability of the mRNA might be altered. If the factor were specific, only c-myc mRNA stability should be affected by a c-myc competitor.

Sense and antisense myc-specific competitor RNAs were synthesized in vitro using the SP6 RNA polymerase promoter linked to fragments from different regions of the 2365-nucleotide c-myc cDNA (Fig. 1A,B). Nonspecific competitor RNAs were generated from human $\beta$.globin and pGEM vector DNAs. Each competitor was added separately to mRNA decay reactions. At various times, the incubations were stopped, RNA was isolated, and the amount of undegraded mRNA was measured by Northern blot or RNase protection analysis, using the probes indicated in Figure 1C. Sense strand competitors from the c-myc $3^{\prime}$ region reduced the c-myc mRNA halflife by at least eightfold, from $40 \mathrm{~min}$ to $<5 \mathrm{~min}$ /Fig. 1, competitors $b-d$; Figs. 2 and 3 ). The following RNA competitors did not destabilize c-myc mRNA: a c-myc antisense fragment from the $3^{\prime}$ region (RNA a), $\beta$-globin, and pGEM RNA (Fig. 2). Therefore, the destabilization effect of RNAs $b-d$ was sequence specific.

The smallest destabilizing fragment tested contained 182 nucleotides of c-myc-coding sequence and lacked $3^{\prime}$ UTR sequences (Fig. 2B, competitor $d$ ). On the basis of this and other observations (see below), this region of c-myc mRNA is referred to as the coding region stability determinant. These in vitro data are completely consistent with observations made on intact cells, implicating the coding region as an important determinant of c-myc mRNA stability and regulation (Lachman et al. 1986; Bonnieu et al. 1988, 1990; Wisdom and Lee 1990, 1991; Laird-Offringa et al. 1991).

To assess whether destabilization could also be induced by a sense RNA competitor from the 5 ' half of the mRNA, polysomes were incubated with RNA e. c-myc mRNA decay was analyzed by RNase protection with a $3^{\prime}$ probe, to avoid hybridization of the $5^{\prime}$ Northern blot probe to the competitor. RNA $e$ had no apparent effect on c-myc mRNA stability (Fig. 3). This result further confirms the sequence specificity of the destabilization effect. It is also consistent with the observation that de- 
Figure 1. c-myc mRNA competitor RNAs used in this study and summary of in vitro half-life measurements. $(A)$ Diagram of c-myc mRNA. Solid lines represent $5^{\prime}$ - and $3^{\prime}$-UTRs. The boxed area represents protein-coding sequences. The hatched box between nucleotides 1705 and 1886, encoding amino acids 357-439, represents the coding region determinant in the mRNA; it also denotes the smallest competitor RNA tested that induced c-myc mRNA destabilization (RNA $d$, see below). Restriction enzyme sites used to generate each competitor RNA are indicated above the line drawing. $(B)$ Competitor RNAs and their effects on the half-life of polysome-associated c-myc mRNA in vitro. The location and orientation of each competitor RNA are indicated relative to the mRNA. Thus, RNA $a$ is from nucleotides 1354-2365 and is antisense to the mRNA. Nonspecific RNAs were generated from a pGEM vector and from human $\beta$-globin cDNA. (Right) The approximate in vitro half-life of $c-m y c$ mRNA in reactions containing the indicated competitor RNA. These numbers represent the average of at least three experiments. $(C)$ Probes used for detecting c-myc mRNA. The Northern blot probe was doublestranded DNA from the indicated region. The RNase protection probe was singlestranded RNA. The straight line indicates homologous sequence; the wavy line represents sequence from the vector.

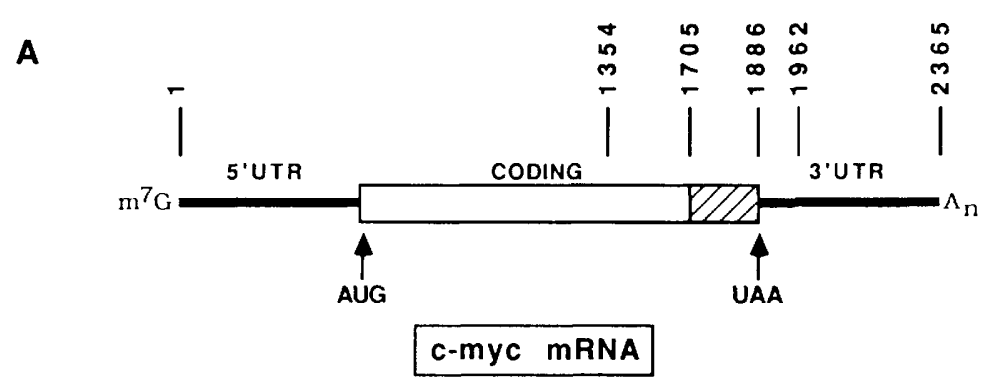

$\mathbf{B}$

RNA COMPETITORS

HALF-LIFE

(minutes)

(NONE)

40

40

40

$<5$

$<5$

$<5$

40

C

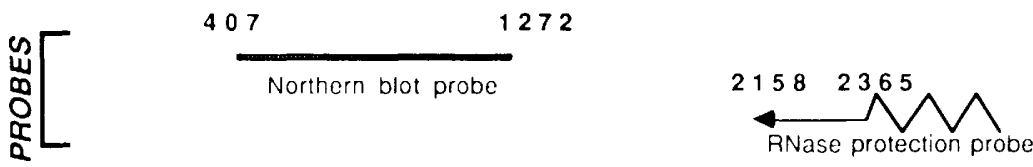

leting most of the c-myc 5'-UTR /and not replacing it with other sequences) has little or no effect on $c-m y c$ mRNA stability in intact cells (Bonnicu et al. 1988; see also Pei and Calame 1988, whose data and conclusions differ from ours and from Bonnieu et al.)

\section{Specificity of the coding region competitor RNAs for $c$-myc mRNA}

The RNA competitors that induce destabilization derive from one region of c-myc mRNA. That is, sense RNAs from the coding region are effective, whereas antisense RNA from the same region and sense RNA from the 5' region are not (Figs. 1-3). To determine whether the coding region competitors affected only c-myc mRNA, the half-lives of four other mRNAs were analyzed. RNA $c$ induced c-myc mRNA destabilization (Fig. 3) but had no effect on $\gamma$-globin, which is polyadenylated and stable, or on histone, which lacks poly(A) and is unstable (Fig. 4, A and $B$, respectively). The decay of the stable GAPDH mRNA was also unaffected by competitor RNA $c$ (data not shown).

The turnover of c-myb mRNA was then analyzed, because, like c-myc, it is polyadenylated and unstable. c-myb mRNA half-life was approximately 23 and $32 \mathrm{~min}$ without and with RNA $d$, respectively, and was therefore not significantly influenced by this competitor (Fig. 5 , boxes). The turnover of AP-4 mRNA was analyzed, because both c-myc and AP-4 mRNAs are thought to encode transcription factors containing a three-motif segment-basic region, helix-loop-helix, and leucine zipper (Blackwell et al. 1990; Luscher and Eisenmann 1990). In this respect, AP-4 and c-myc mRNAs are even more closely related than c-myb and c-myc mRNAs. However, AP-4 mRNA was not destabilized in reactions containing RNA $d$ (Fig. 5, circles). Its in vitro half-life was $28 \mathrm{~min}$, with or without competitor. Therefore, the 182-nucleotide RNA $d$ competitor does not destabilize every mRNA and shows considerable specificity for c-myc mRNA.

The 182-nucleotide RNA d competitor seems to expose an endonuclease-sensitive site and is effective in destabilizing a heterologous mRNA containing the myc-coding region determinant

Two observations suggest that RNA competitors $b-d$ induce c-myc mRNA destabilization by exposing an endonuclease cleavage site within the coding region determinant. First, the asterisks in Figure 2 indicate a band (iden- 
A
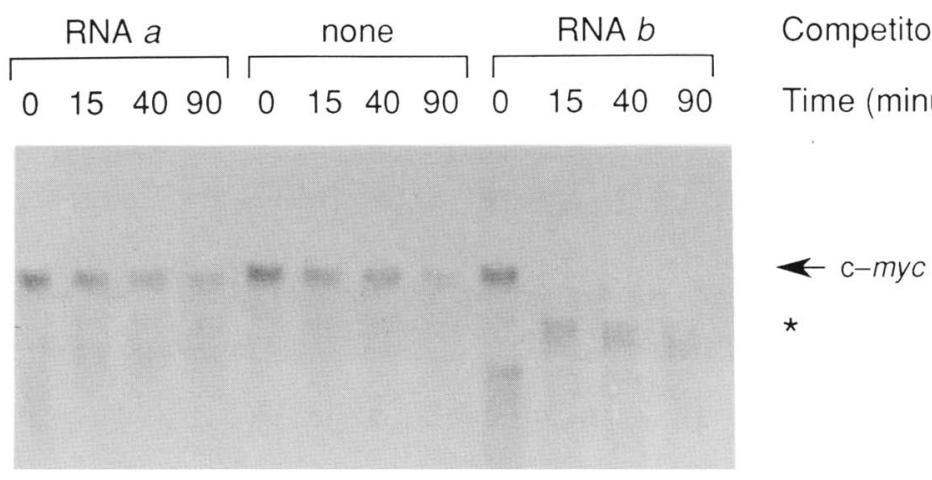

$\begin{array}{llllllllllll}1 & 2 & 3 & 4 & 5 & 6 & 7 & 8 & 9 & 10 & 11 & 12\end{array}$

B
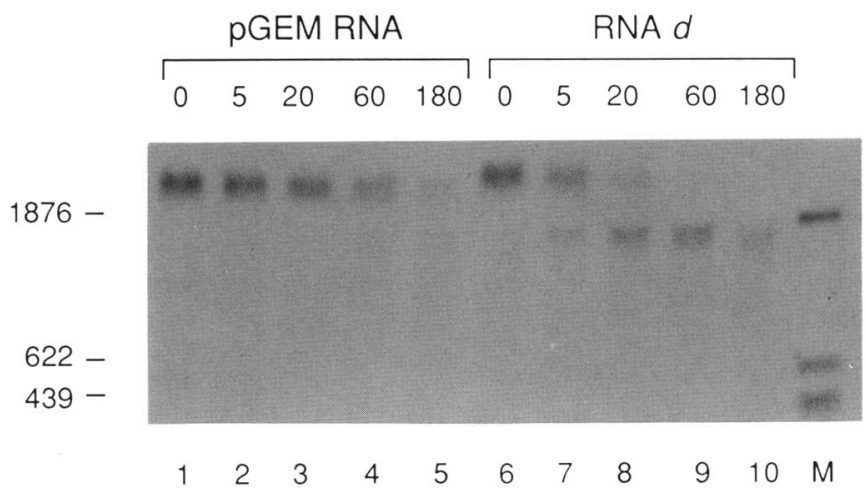

tified using a $5^{\prime}$-specific c-myc probc/ with propertics expected of a $5^{\prime}$ endonuclease-generated decay product. It contains $\sim 1800$ nucleotides, consistent with a cleavage product spanning from the cap site to approximately nucleotide 1800 (see map, Fig. 1A). It was generated only in reactions containing RNA competitors $b-d$, which induced the destabilization effect (Fig. 2B, cf. lanes 1-5

\section{Competitor RNA \\ Time (minutes)}

Figure 2. Effect of competitor RNAs on the in vitro decay of polysome-associated c-myc mRNA. $(A)$ Competitors $a$ and $b$. Standard in vitro mRNA decay reactions contained $0.7 A_{260}$ units of polysomes and were either unsupplemented (lanes 5-8, none) or supplemented with $1 \mu \mathrm{g}$ of competitor RNAs corresponding to the 1012 terminal nucleotides of c-myc mRNA, either in the antisense (lanes 1-4, RNA $a$ ) or sense (lanes 9-12, RNA b) orientation. Each reaction was incubated for the times indicated, RNA was extracted, and $5 \mu \mathrm{g}$ Competitor RNA was electrophoresed. Following transfer to a membrane, c-myc mRNA levels were analyzed by hybridization with a $5^{\prime} \mathrm{c}-\mathrm{myc}$ specific probe (see Fig. 1C). The asterisk (*) indicates a possible c-myc mRNA endonucleolytic decay product (see Results and Discussion). $(B)$ Competitor $d$ (conditions were as described for $A$ ). In vitro mRNA decay reactions were supplemented with 1 $\mu \mathrm{g}$ of either $\mathrm{PGEM}$ vector RNA (lanes $1-5$ ) or competitor $d$ (lanes 6-10). Lane $M$ contains radiolabeled pBR322 DNA cleaved with HaeII; fragment sizes are indicated in nucletides at left. (") See $A$ for explanation.

with 6-10). As expected for a short-lived decay product, it appeared and then disappeared as the mRNA was being degraded. Second, decay products with termini in the $3^{\prime}$-UTR were not observed in reactions containing the destabilizing competitor $c$ (Fig. 3, lanes 5-8). We have consistently detected 3 ' region decay products in reactions containing polysomes alone (Brewer and Ross
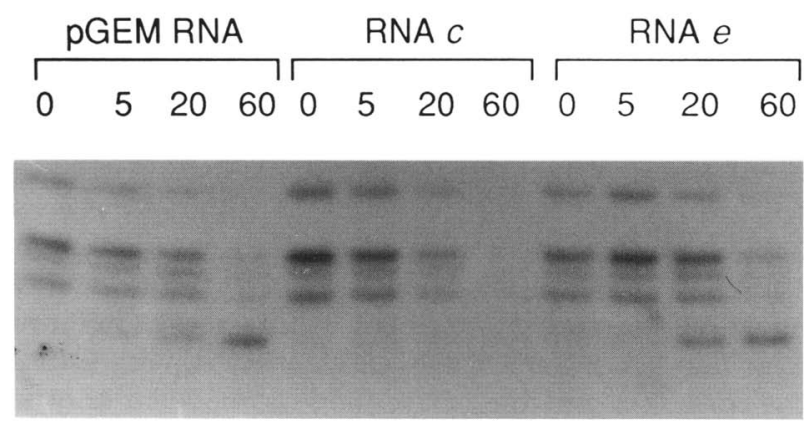

1

\section{Competitor RNA} Time (minutes)

$\mathrm{c}-m y c$
Figure 3. Effect of sense strand RNA competitors from the $5^{\prime}$ and $3^{\prime}$ regions of c-myc mRNA on c-myc mRNA stability in vitro. $m R N A$ decay reactions were performed as described in Fig. 2. RNase protection was carried out by hybridizing $5 \mu \mathrm{g}$ of RNA from each time point to a uniformly labeled c-myc RNA probe (see Fig. 1). The four protected bands indicated by the bracket represent full-length, undegraded c-myc mRNAs, which terminate at four different but nearby polyadenylation sites (Brewer and Ross 1988). The half-life of the four protected bands in the presence of nonspecific RNA or RNA $e$ was $60 \mathrm{~min}$; the half-life with RNA $c$ was $15 \mathrm{~min}$. The arrowhead indicates $3^{\prime}$ region $c-m y c$ mRNA decay products (Brewer and Ross 1988; see Results|. 
A

Figure 4. Effect of c-myc RNA competitors on $\gamma$-globin and histone mRNA stability in vitro. (A) $\gamma$-Globin mRNA. mRNA decay reactions were carried out as per Fig. 2. One microgram of RNA from each time point was analyzed by hybridization to an end-labeled $\beta$-globin ${ }^{32} \mathrm{P}$-labeled DNA probe, followed by S1 nuclease digestion. The protected fragment was analyzed by electrophoresis in a $7 \mathrm{M}$ urea $/ 6 \%$ polyacrylamide gel and quantitated by scanning densitometry. The arrow indicates the band corresponding to undegraded $\gamma$-globin mRNA. Less than $10 \%$ of the mRNA was degraded during the reaction. (B) Histone mRNA. RNA (1.5 $\mu \mathrm{g})$ from each time point was hybridized to a $3^{\prime}$ end-labeled $\mathrm{H} 4$ histone ${ }^{32}$ P-labeled DNA probe, followed by $\mathrm{S} 1$ nuclease digestion. The protected fragment was analyzed by electrophoresis in a $7 \mathrm{M}$ urea/ $10 \%$ polyacrylamide gel. The band corresponding to the full-length protected probe is indicated by the arrow. Lower molecular weight bands are decay products. The half-life of histone mRNA was $20 \mathrm{~min}$ in each reaction.

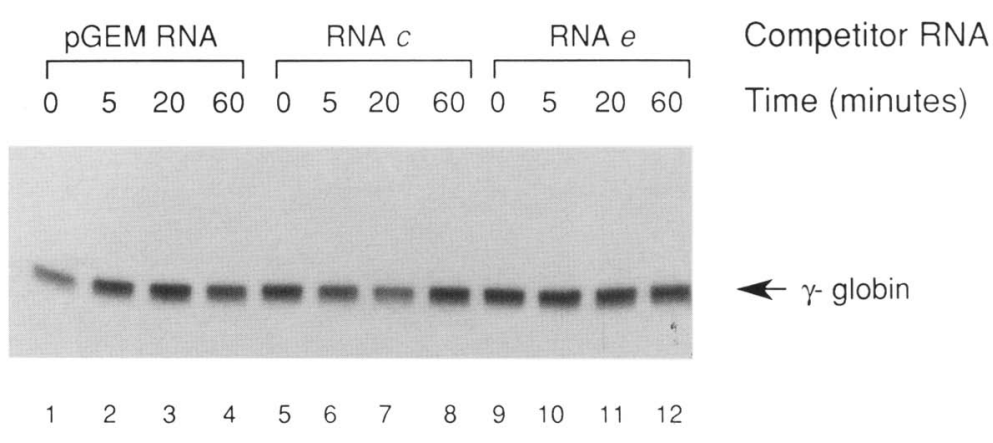

B
1988). They arise as part of a two-step decay pathway: poly(A) shortening followed by $3^{\prime} \rightarrow 5^{\prime}$ decay of the mRNA body. The $3^{\prime}$ decay products were observed in reactions containing nonspecific RNA or RNA $e$ (Fig. 3, lanes 1-4 and 9-12) but not in reactions containing RNA $c$ (lanes 5-8). This result confims that $c-m y c$ mRNA was degraded by a different pathway when RNA $c$ was present. Taken together, the data from Figures 2 and 3 suggest that the destabilizing competitor RNAs function by titrating away a protective factor from the c-myc mRNA-coding region, inducing rapid degradation by an alternate endonucleolytic pathway.

To determine whether the c-myc-coding region determinant is sufficient to influence mRNA turnover and contains an endonuclease-sensitive site, we examined the effect of this region in the context of a stable mRNA molecule. The carboxy-terminal $249 \mathrm{c}$-myc-coding nucleotides were fused in-frame within the $\beta$-globin gene, so that the resulting chimeric mRNA would initiate and terminate translation at the usual globin sites and would encode a complete globin protein interrupted by $\mathrm{c}-\mathrm{myc}$ residues 357-439 (amino acid 439 is at the c-myc carboxyl terminus; Fig. 6A). The chimeric gene was subcloned into a cytomegalovirus (CMV) promoter-driven eukaryotic expression vector, the gene was introduced into HeLa cells, and a pool of hygromycin-resistant cells synthesizing the chimeric mRNA was selected. As determined by exposing cells for $2 \mathrm{hr}$ to actinomycin $\mathrm{D}$ and measuring mRNA levels, the half-life of the chimeric mRNA was only twofold less than that of unmodified $\beta$-globin mRNA (data not shown). There are several possible interpretations of this observation. One is that the chimeric mRNA is unstable, but not in the presence of actinomycin D (Wisdom and Lee 1991). Another is that the c-myc-coding region determinant has no effect on mRNA stability in growing cells but functions only under special circumstances, for example, during cell differentiation or following drastic changes in the cell grow th rate (see Discussion). In either case, the stability of the chimeric mRNA in actinomycin-treated cells is reflected in vitro in reactions lacking destabilizing competitor RNAs (Fig. 6B,C).

Polysomes were isolated from the transfected HeLa cells and incubated with or without competitor RNA $d$. Endogenous c-myc mRNA was unstable in unsupplemented reactions, indicating that in vitro reactions with HeLa cell polysomes reflect the intracellular lability of c-myc mRNA (Fig. 6B,C, lanes 1-4). GlobMycGlob chimeric mRNA was stable during the $1-$ hr time course in unsupplemented reactions (Fig. 6B, lanes 1-4). Therefore, the coding region determinant per se did not confer instability to a normally stable mRNA. RNA $d$ addition reduced the half-life of the chimeric mRNA by at least 20 -fold, to $<5 \mathrm{~min}$, similar to its effect on endogenous c-myc mRNA (Fig. 6B, lanes 5-8). Therefore, the 249 nucleotide segment contains a coding region determinant that can influence mRNA stability in vitro within the context of a stable mRNA and independent of other c-myc sequences.

Moreover, the 249-nucleotide region probably con- 


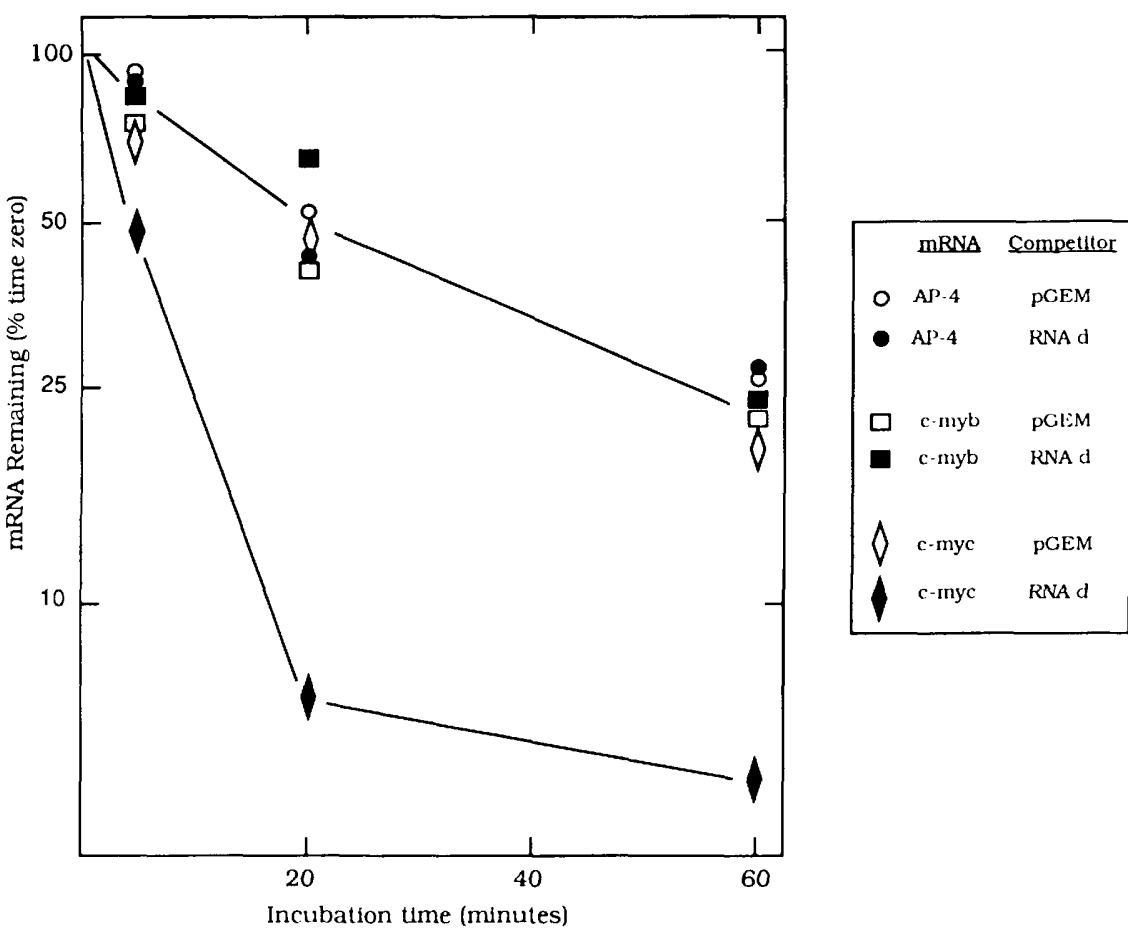

Figure 5. Specificity of competitor RNAinduced destabilization of c-myc mRNA: failure to destabilize c-myb and AP-4 mRNAs. mRNA decay reactions, performed as described in Fig. 2, were supplemented with either pGEM RNA or com petitor RNA $d$. Total RNA extracted from each reaction was analyzed by Northern blotting with probes for c-myb, AP-4, and c-myc mRNAs. The amount of undegraded mRNA remaining at each time point was quantitated by scanning densitometry. The half-lives (in $\mathrm{min}$ ) of each mRNA without and with RNA $d$, respectively, were 23 and 32 for c-myb, 28 and 28 for AP-4, and 28 and $<5$ for c-myc. tains an endonuclease cleavage site. The asterisk in Figure $6 \mathrm{~B}$ indicates a band that appeared only in reactions with competitor RNA $d$. Its size, $\sim 570$ nucleotides, is consistent with its being a $5^{\prime}$ decay product generated by endonuclease cleavage within the c-myc segment of GlobMycGlob mRNA. The possibility that the $\sim 570$ nucleotide band was a $3^{\prime}$ decay product from endogenous c-myc mRNA was excluded, because the blot was stripped and rehybridized with a $5^{\prime}-\beta$-globin probe, which also detected the $\sim 570$-nucleotide band (Fig. $6 \mathrm{C}$ ). In summary, the c-myc-coding region determinant can, under appropriate circumstances, influence mRNA stability in vitro without additional c-myc sequences, and it contains an endonuclease-sensitive site.

\section{Identification of a protein that interacts specifically with the c-myc RNA competitor $\mathrm{d}$}

The data presented above are consistent with the following hypothesis: A c-myc mRNA-specific factor (protein) is associated with polysomes, perhaps bound to the mRNA itself. Addition of competitor RNA from the carboxy-terminal 182 nucleotides of the coding region titrates the protein away from the polysomes, leading to accelerated c-myc mRNA decay. To assess this possibility, gel mobility-shift assays were performed. Uniformly radiolabeled RNA $d$ was incubated with polysomes in a mock mRNA decay reaction, to allow RNA-protein (RNP) complexes to form. The reaction mixture was treated with RNase $\mathrm{Tl}$ to digest free RNA, followed by heparin to dissociate loosely bound complexes. RNP complexes were distinguished from unbound RNA by electrophoresis in a nondenaturing gel and autoradiogra- phy. A slower migrating RNP band was observed in reactions containing polysomes plus ${ }^{32}$ P-labeled RNA $d$ (Fig. 7A, cf. lanes 1 and 2). This band was not generated with $\beta$-globin ${ }^{32}$ P-labeled RNA (lane 3 ) or when polysomes were pretreated with trypsin, indicating that the band shift depended on the interaction of a polysomal protein with ${ }^{32}$ P-labeled RNA $d$ (lane 4).

To determine whether the protein could be solubilized and separated from polysomes, as is the case with polysome-associated RNases (Ross et al. 1987), polysomes were incubated on ice with $1 \mathrm{M} \mathrm{NaCl}$ and then centrifuged, pelleting the polysomes and leaving a supernatant, termed ribosomal salt wash (RSW). When RSW was analyzed by gel-shift assay with ${ }^{32}$ P-labeled RNA $d$, a slower migrating band was observed (Fig. 7A, lane 5). Its mobility was similar or identical to the gel-shifted band generated with polysomes (lanes 2,5), and its appearance was trypsin sensitive (lane 6). Therefore, the same protein in polysomes and RSW was probably responsible for binding to RNA $d$. This observation is important for two reasons. First, it confirms the noncovalent interaction of the protein with polysomes or c-myc mRNA, as evidenced by its displacement with either competitor RNA or high salt. Second, the ability to solubilize the protein in active form should facilitate its purification.

To confirm the specificity of the RNA-protein interaction, gel-shift analyses were performed by incubating polysomes with ${ }^{32} \mathrm{P}$-labeled RNA $d$ in the presence of unlabeled RNA. As much as $200 \mathrm{ng}$ of unlabeled $\beta$-globin RNA, corresponding to a 200 -fold molar excess over ${ }^{32} \mathrm{P}-$ labeled RNA $d$, failed to eliminate the gel-shifted band (Fig. 7B, lane 4). At $500 \mathrm{ng}$ of unlabeled $\beta$-globin RNA (a 500 -fold molar excess), the gel-shifted band was dimin- 

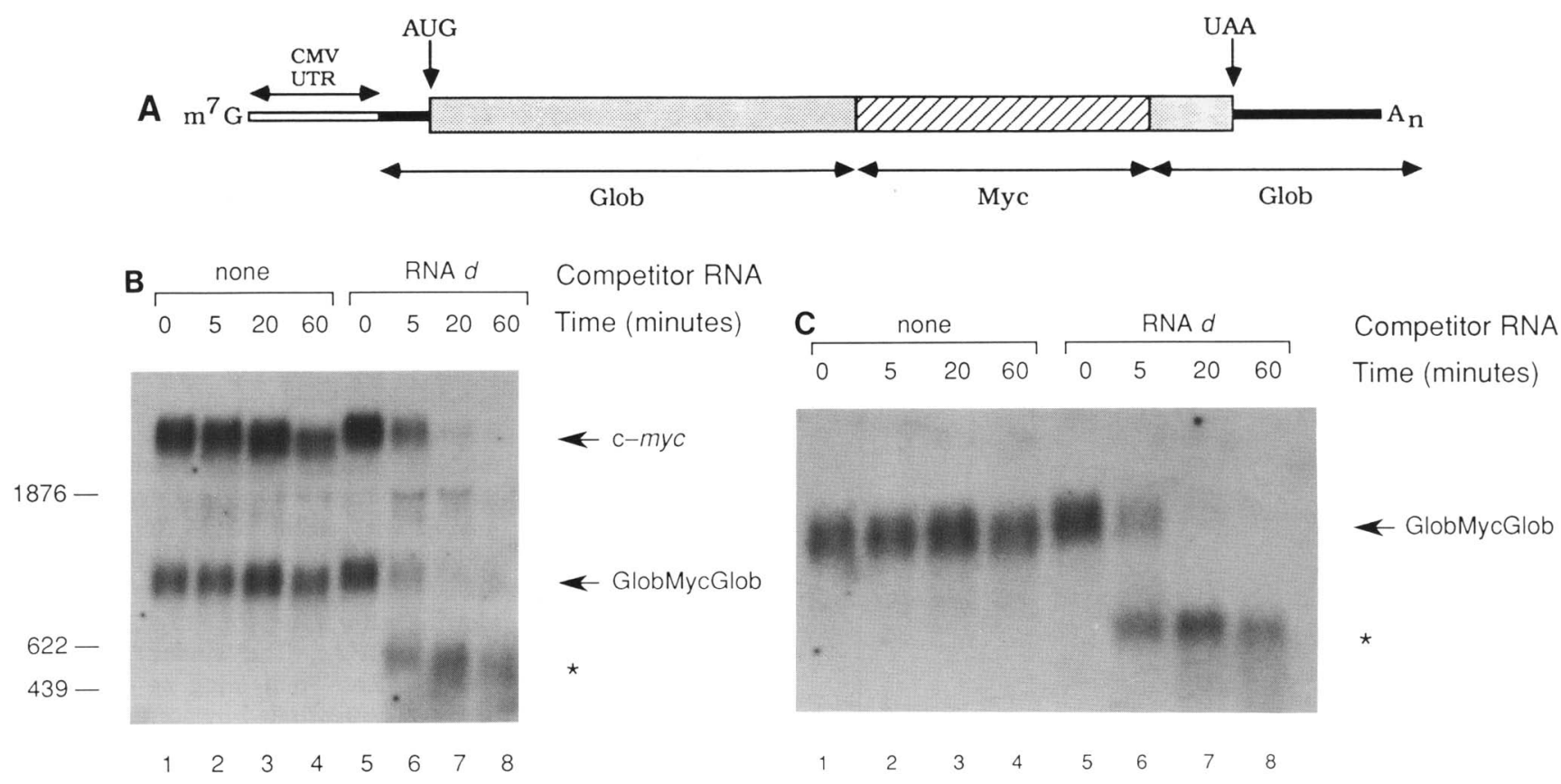

Figure 6. Competitor RNA-induced destabilization of chimeric GlobMycGlob mRNA (1006 nucletides) containing 249 nucleotides from the c-myc mRNA carboxy-terminal coding region. (A) Diagram of chimeric mRNA gencrated from the GlobMycGlob transfected gene. A 249-bp fragment from the c-myc gene (hatched box) was placed into the EcoRI site of a human $\beta$-globin gene (see Materials and methods). The c-myc fragment includes the entire 182 nucleotides of RNA $d$ plus 67 nucleotides $5^{\prime}$ of the RNA $d$ segment. Therefore, all c-myc sequences are derived from the coding region (amino acids 357-439). Sequencing of the construct confirmed that the c-myc segment was in-frame and that translation should begin and end at $\beta$-globin initiation and termination sites, which are noted. In summary, the protein encoded by this mRNA will contain globin amino acids $1-121$, followed by c-myc amino acids 357-439, followed by globin amino acids 122-146. The shaded boxes denote $\beta$-globin-coding sequences, the open bar denotes the 5 '-UTR sequences from CMV; the solid bars indicate the $\beta$-globin untranslated regions. Methods for transfecting HeLa cells and selecting a stable pool of transformants expressing this mRNA are described in Materials and methods. $(B)$ Destabilization by competitor $d$ : analysis with a probe recognizing both globin and c-myc sequences. Polysomes were isolated from HeLa cells expressing the GlobMycGlob gene and were incubated in cell-free mRNA decay reactions with or without competitor RNA $d$. RNA extracted from each time point was analyzed by Northern blotting, using a hybrid gene probe containing the HindIII-EcoRI $5^{\prime} \beta$-globin fragment fused to the ClaI-EcoRI fragment of the human c-myc gene. This probe hybridizes to GlobMycGlob and to endogenous $c-m y c$ mRNAs and recognizes both globin and c-myc sequences. Arrows denoting c-myc and GlobMycGlob (right) indicate the expected positions of the respective undegraded mRNAs. The sizes (in nucleotides) of DNA marker fragments coelectrophoresed are noted at left. The asterisk $\left({ }^{*}\right)$ denotes putative endonuclease decay product. $(C)$ Destabilization by competitor $d$ : analysis with a probe recognizing only $5^{\prime}$-globin sequences. The blot in $B$ was stripped and reprobed with a radiolabeled DNA fragment prepared from the $5^{\prime}$ region of the $\beta$-globin gene. The asterisk (") denotes putative endonuclease decay product.

ished in intensity but was not eliminated (lane 5). In contrast, only $50 \mathrm{ng}$ of unlabeled RNA $d$ diminished the intensity of the gel-shifted band (cf. lanes 5 and 6 ). We conclude that the RNA-binding protein specifically recognizes c-myc mRNA sequences from the carboxy-terminal-coding region.

RNA-protein cross-linking by UV light was used to estimate the molecular weight of the binding proteins. Binding reactions were carried out as for the gel shifts, but reaction mixtures were exposed to UV light prior to electrophoresis, so as to link the protein covalently to the ${ }^{32}$ P-labeled RNA substrate. The RNP was then digested with RNase A and analyzed by SDS-PAGE and autoradiography. A protein of $\sim 75-\mathrm{kD}$ was detected when RSW and ${ }^{32} \mathrm{P}$-labeled RNA $d$ were mixed and UVcross-linked (Fig. 8, lane 3). Cross-linking required both RSW and UV light (cf. lane 3 with lanes 1 and 2 ) and was eliminated by pretreating the RSW with trypsin (lane 4). When pGEM vector ${ }^{32} \mathrm{P}$-labeled RNA was used instead of c-myc fragment $d$, the $\sim 75-\mathrm{kD}$ protein was not labeled (lanes 6,7). These results confirm the specificity of the RNA-protein interaction for c-myc sequences and identify a polysome-associated, $\sim 75-\mathrm{kD}$ protein responsible for binding.

Two considerations prompted us to test whether the $\sim 75-\mathrm{kD}$ protein might be poly(A)-binding protein (PABP). First, adenylate residues comprise $35 \%$ of RNA $d$, and some are clustered (Fig. 9). Second, the molecular weights of the UV-cross-linked protein and PABP are similar (Adam et al. 1986; Sachs et al. 1986; Grange et al. 1987). Yeast PABP synthesized in bacteria binds to poly(A) and affects mRNA stability in our cell-free system (Bernstein et al. 1989). However, when $1 \mu \mathrm{g}$ of yeast PABP was mixed with polysomes and UV-cross-linked, 
A
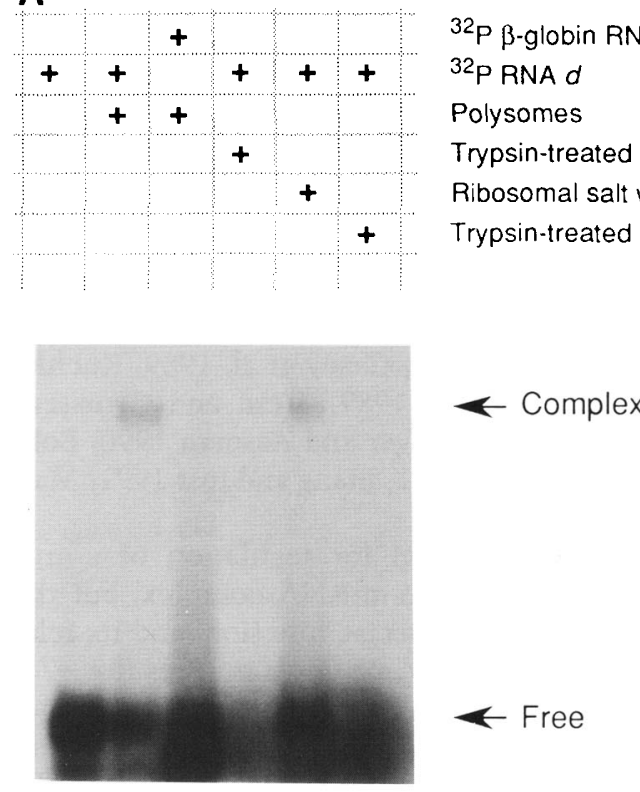

$\begin{array}{llllll}1 & 2 & 3 & 4 & 5 & 6\end{array}$

\author{
${ }^{32} \mathrm{P} \beta$-globin RNA \\ ${ }^{32} \mathrm{P}$ RNA $d$ \\ Polysomes \\ Trypsin-treated polysomes \\ Ribosomal salt wash \\ Trypsin-treated ribosomal salt wash
}
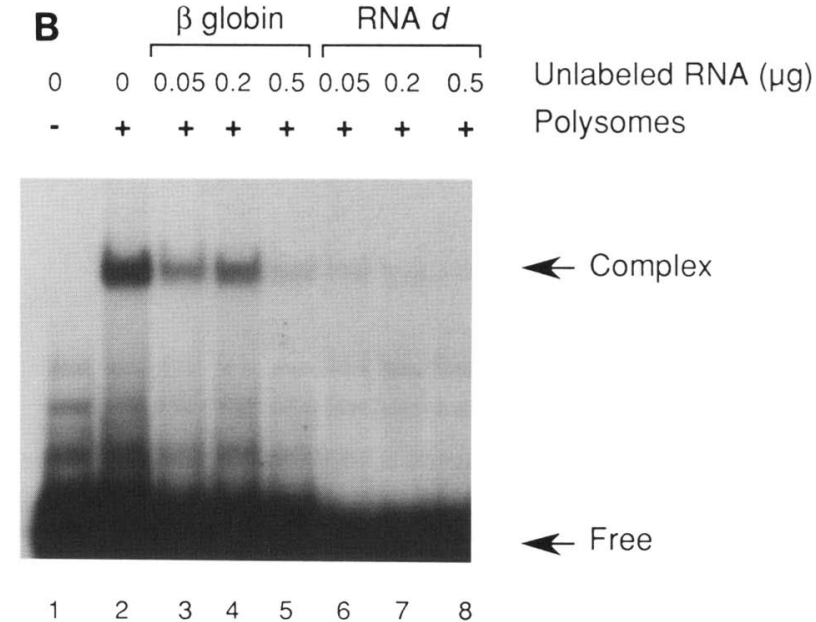

Figure 7. Gel-shift analyses: binding of polysome-associated protein to competitor RNA $d$. (A) Uniformly ${ }^{32} \mathrm{P}$-labeled competitor RNA $d$ was incubated with polysomes in a mock decay reaction (Materials and methods), and protein-RNA complex formation was assessed by electrophoresis in a $6 \%$ nondenaturing polyacrylamide gel. (Lane 1) Input ${ }^{32} \mathrm{P}$-labeled RNA $d$, no polysomes; (lane 2) ${ }^{32} \mathrm{P}$-labeled RNA $d$ plus polysomes; (lane 3$)^{32} \mathrm{P}$-labeled $\beta$-globin transcript (200 nucleotides) plus polysomes; (lane 4) ${ }^{32} \mathrm{P}$-labeled RNA $d$ plus polysomes pretreated with trypsin; (lane 5$)^{32} \mathrm{P}$-labeled RNA $d$ plus $1 \mu \mathrm{g}$ of RSW protein, corresponding to material solubilized from the same number of polysomes analyzed in lane 2; (lane 6) ${ }^{32}$ P-labeled RNA $d$ plus RSW pretreated with trypsin. $(B)$ Effect of unlabeled RNAs on the gel shift of ${ }^{32} \mathrm{P}$-labeled RNA $d$. The amounts $(\mu \mathrm{g})$ of each unlabeled RNA are indicated above the lanes. (Lane 1) Input ${ }^{32} \mathrm{P}$-labeled RNA $d$, no polysomes; (lane 2) ${ }^{32} \mathrm{P}$-labeled RNA $d$ plus polysomes; (lanes $3-5$ ) ${ }^{32} \mathrm{P}$-labeled RNA $d$ plus polysomes plus unlabeled $\beta$-globin RNA; (lanes $6-\left.8\right|^{32}$ P-labeled RNA $d$ plus polysomes plus unlabeled RNA $d$.

the $\sim 75-\mathrm{kD}$ band was not detected (Fig. 8, lane 5). Therefore, the $\sim 75-\mathrm{kD}$ protein was probably not PABP.

\section{Discussion}

We are using in vitro assays to search for cellular proteins with two properties: the capacity to bind to a discrete region of a single polysomal mRNA and the capacity to influence the half-life of that mRNA. To screen for such proteins, sense and antisense RNAs corresponding to various segments of $c-m y c$ mRNA were added to a cell-free mRNA decay system containing polysomes. The half-life of c-myc mRNA was then compared in reactions with or without the exogenous RNA.

These assays identified a sense strand RNA fragment that reduced the half-life of c-myc mRNA by at least eightfold. The RNA fragment corresponded to the carboxy-terminal 182 nucleotides of the mRNA-coding region and was cross-linked by UV light to a polysomal protein of $\sim 75 \mathrm{kD}$. The following observations indicated a considerable degree of specificity for the c-myc mRNA-protein interaction and for the destabilization effect: (1) Only c-myc mRNA was destabilized in vitro by the 182-nucleotide RNA; the half-lives of other
mRNAs were unaffected. (2) Other competitor RNA fragments, including one from the $c-m y c 5^{\prime}$ region, failed to destabilize c-myc mRNA. (3) A chimeric mRNA containing 249 nucleotides from the c-myc-coding region, which included the 182-nucleotide sequence, was destabilized in vitro by the competitor. To account for these observations, we suggest that the 182-nucleotide RNA titrated the $\sim 75-\mathrm{kD}$ protein away from c-myc mRNA, exposing an endonuclease-hypersensitive site in the coding region determinant and destabilizing the mRNA / see below).

There are at least two important caveats with regard to this interpretation. First, while the $\sim 75-\mathrm{kD}$ protein sediments with polysomes, we have not demonstrated that it is actually bound to c-myc mRNA. However, if the protein were associated with ribosomes or with many mRNAs, rather than with a single mRNA, it would be difficult to account for the considerable specificity of the destabilization effect. Second, we have not added purified $\sim 75-\mathrm{kD}$ protein back to MRNA decay reactions and shown restoration of the $40-\mathrm{min}$ half-life. Experiments are in progress to purify and characterize the protein. Two of its properties suggest that it is not related to the recently described AU-binding proteins (Malter 1989; Bohjanen et al. 1991; Brewer 1991; Malter and Hong 


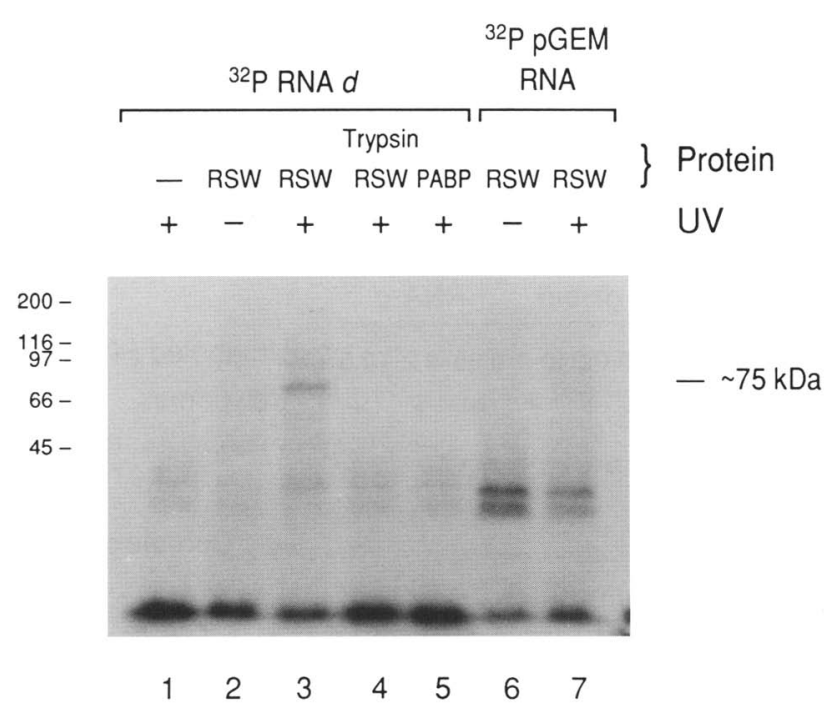

Figure 8. UV-cross-linking of a RSW protein to ${ }^{32} \mathrm{P}$-labeled RNA $d$. Uniformly ${ }^{32}$ P-labeled labeled RNA $d$ was incubated with $1 \mu \mathrm{g}$ of RSW protein in a mock mRNA decay reaction and exposed to UV light (Materials and methods). Reactions mixtures were treated with RNase A, boiled in SDS-PAGE sample loading buffer, and analyzed in a $10 \%$ SDS-polyacrylamide gel. Numbers at left indicate molecular masses $(\mathrm{kD})$ of coelectrophoresed protein markers. (Lane 1) No RSW; (lane 2) complete reaction containing RSW and ${ }^{32} \mathrm{P}$-labeled RNA $d$, but no UV; (lane 3) complete reaction, plus UV; (lane 4) same as lane 3, but RSW pretreated with trypsin; (lane 5) same as lane 3 , but $1 \mu \mathrm{g}$ of PABP in place of RSW; (lanes 6,7 ) reaction carried out with ${ }^{32} \mathrm{P}$-labeled pGEM RNA in place of RNA $d$, either with (lane 7) or without (lane 6) subsequent exposure to UV light.

1991; Vakalopoulou et al. 1991): (1) The sizes of the proteins differ; and (2) the carboxy-terminal-coding region of c-myc mRNA is purine rich but not AU rich (Fig. 9A).

Three observations indicate that c-myc mRNA is not degraded by the previously described two-step pathway [poly|A) shortening, followed by $3^{\prime} \rightarrow 5^{\prime}$ decay (Brewer and Ross 1988)] in reactions containing destabilizing competitor RNAs. Rather, the data imply that an endonuclease cleavage site becomes exposed when the $\sim 75$ $\mathrm{kD}$ protein is titrated away from the $\mathrm{c}-\mathrm{myc}$-coding region determinant. (1) A short-lived c-myc decay product of $\sim 1800$ nucleotides appears during incubations containing the destabilizing RNAs $b$ and $d$ (denoted by asterisks in Fig. 2). Its size corresponds to the $5^{\prime}$ fragment generated by endonuclease cleavage within the c-myc-coding region determinant (nucleotides 1705-1886). (2) The $\sim 1800$-nucleotide product is not observed in reactions lacking destabilizing RNAs (Fig. 2). Conversely, products of the two-step pathway (denoted by the arrows in Fig. 3, lanes 1-4 and 9-12) are observed only in reactions containing RNAs that fail to generate the $\sim 1800$-nucleotide product. (3) In reactions containing competitor RNA $d$, a decay product from the GlobMycGlob chimeric mRNA is the expected size of an endonuclease cleavage product (denoted by asterisks in Fig. 6B,C).

The existence of two distinct cytoplasmic stability de- terminants in c-myc mRNA, one in the $3^{\prime}$-UTR and another in the coding region, has been well-documented in intact cells by transfection experiments with chimeric gene constructs (Bonnieu et al. 1988; Wisdom and Lee 1991). Coding region stability determinants have also been described in c-fos, tubulin, and interleukin-2 (IL-2) $\alpha$-receptor mRNAs (Yen et al. 1988a,b; Shyu et al. 1989, 1990; Kanamori et al. 1990). Our results are also consistent with experiments describing trans-acting factors that influence the half-lives of specific mRNAs in intact cells (Schuler and Cole 1988; Casey et al. 1989; Kuchka et al. 1989; Mullner et al. 1989; Stern and Gruissem 1989; Weber et al. 1989; Wager and Assoian 1990; Bohjanen et al. 1991; Brewer 1991; Liang and Jost 1991; Malter and Hong 1991).

Our data suggest a model for regulation of c-myc mRNA stability by a protein-mRNA complex, but the nature of the complex, its precise function, and its relationship to translation, if any, are unclear. Does the $\sim 75$. $\mathrm{kD}$ protein actually bind within the 182 -nucleotide coding region determinant and protect that region from endonucleolytic attack? If so, is the protein-mRNA association influenced by trans-acting mRNA stability regulatory factors? If separate mRNA stability determinants exist in the c-myc $3^{\prime}$-UTR and coding region, does each function separately and respond to different regulatory factors? Docs the protein remain bound while the mRNA is being translated?

For discussion purposes, we might assume that the coding region determinant, in its unprotected state, is a ready target for endonuclease digestion. However, this region consists entirely of protein-coding sequences; and, in growing cells, ribosomes might pass continously through the region, displacing any bound proteins and perhaps blocking both the protein binding site and the endonuclease cleavage site. How, then, could the $\sim 75$ $\mathrm{kD}$ protein protect the mRNA from decay? If ribosomes protected the site and/or blocked access to it, a protective protein would be superfluous.

On the other hand, if c-myc mRNA were not uniformly translated, and if ribosomes paused just upstream of or within the coding region determinant, the resulting ribosome-free segment might become an endonuclease target site (Fig. 9B). Perhaps the $\sim 75-\mathrm{kD}$ protein serves to protect the mRNA from the consequences of ribosome pausing. There are many examples of ribosome pausing: while the signal recognition particle interacts with the signal sequence (for review, see Walter et al. 1984; Siegel and Walter 1988), at translation initiation and termination codons (Lindhout et al. 1985; Wolin and Walter 1988; for review, see Kozak 1991), at a site where an aminoacyl-tRNA is limiting (Scornik 1988), at sites of interaction of the nascent peptide with another protein (Kim et al. 1991), and perhaps also at other sites determined by nonsense or rare codons, frameshifting, ribosome hopping, or folding of the nascent peptide within the ribosomal tunnel or at the exit domain (Chen et al. 1984; Hoekema et al. 1987; Ross 1988; Theodorakis et al. 1988; Atkins et al. 1990; Ito et al. 1990; Picking et al. 1991). The c-myc-coding region determinant encodes 
ACCAGATCCCGGAGTTGGAAAACAATGAAAAGGCCCCCAAGGTAGTTATC

CTTAAAAAAGCCACAGCATACATCCTGTCCGTCCAAGCAGAGGAGCAAAA

GCTCATTTCTGAAGAGGACTTGTTGCGGAAACGACGAGAACAGTTGAAAC

ACAAACTTGAACAGCTACGGAACTCTTGTGCG

$\mathbf{B}$

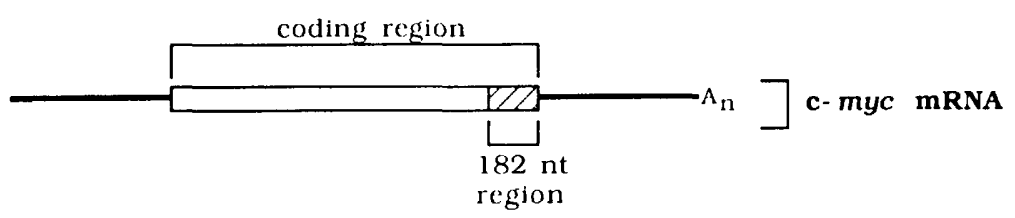

uninterrupted translation
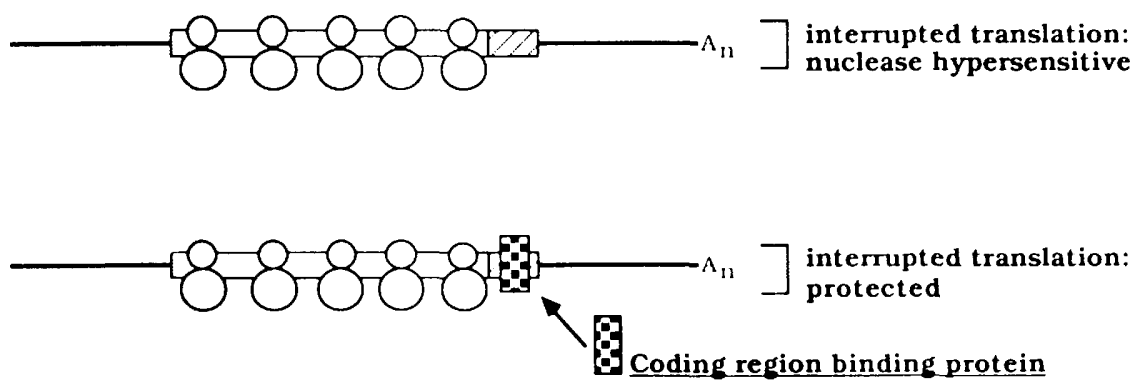

Figure 9. Structure and possible function of the 182-nucleotide coding region determinant of c-myc mRNA stability and the $\sim 75-\mathrm{kD}$ binding protein. $(A)$ Sequence. Purines comprise $58 \%$ of this sequence. The terminal GCG is the last codon before the terminator. $(B)$ Model for possible links between translation, ribosome pausing, binding of the putative $\sim 75-\mathrm{kD}$ protective protein to the coding region determinant, and blocking of an endonuclease-sensitive site. The stacked circles indicate ribosomes translating the mRNA \{see text for details). part of the helix-loop-helix and all of the leucine zipper. It can potentially form several duplex segments, as determined both by computer modeling and by chemical and enzymatic digestion studies (J. Lee, pers. comm.). It also contains $58 \%$ purines, some clustered, similar to the destabilizing segment in the c-fos mRNA-coding region (Fig. 9A; Shyu et al. 1990). Thus, it seems reasonable to propose that a ribosome-free region could result from one of two processes: (1) ribosome stalling enhanced by binding of the $\sim 75-\mathrm{kD}$ protein; or (2) ribosome stalling occurring independent of the protein, followed by binding of the protein to the ribosome-free region. Experiments are in progress to investigate these alternatives and to determine whether the $\sim 75-\mathrm{kD}$ protein regulates translation as well as mRNA stability.

In either case, the existence of separate, independently regulated stability determinants in a single mRNA would permit cells to respond in different ways to changes in nutrient levels, growth factors, and differentiation agents. For example, a differentiation factor might influence the abundance of the $\sim 75-\mathrm{kD}$ protein described here, whereas a growth factor might affect a different regulatory protein that interacts with the 3 'UTR. Recent experimental evidence supports this notion. A region of $c-m y c$ mRNA (encompassing the one described here) functions as an mRNA destabilizing element in a cell line capable of differentiating to form myotubes in culture (Wisdom and Lee 1990, 1991). Furthermore, evidence consistent with this notion and with alternate intracellular decay pathways was obtained by comparing c-myc mRNA decay rates in growing versus differentiating promyelocytic tissue culture cells (Swartwout and Kinniburgh 1989). In exponentially growing cells, deadenylation preceded destruction of the mRNA body, similar to the two-step pathway observed in reactions lacking competitor RNAs (Brewer and Ross 1988). In contrast, when the promyelocytic cells were induced to differentiate to myelocytes, c-myc mRNA disappeared without going through a deadenylation step, suggesting decay by a novel endonucleolytic pathway. Perhaps this pathway was induced by modifying c-myc mRNA-protein interactions, as suggested by our in vitro data. To test this possibility, the half-lives and decay pathways of modified c-myc mRNAs lacking either the coding or the 
3'-UTR determinant can be compared during promyelocyte differentiation.

\section{Materials and methods}

In vitro $M R N A$ decay reactions

The culturing of human erythroleukemia cells (K562) and the isolation of polysomes, which are the source of both endogenous messenger ribonucleoprotein (mRNP) and mRNA-degrading enzymes, were performed as described previously (Ross and Kobs 1986; Ross et al. 1987). Briefly, exponentially growing cells were harvested, washed in cold F12 medium, and lysed with a Potter-Elvehjem homogenizer in low salt buffer $11 \mathrm{~mm}$ potassium acetate, $1.5 \mathrm{~mm}$ magnesium acetate, $2 \mathrm{~mm}$ dithiothreitol (DTT), $10 \mathrm{~mm}$ Tris- $\mathrm{HCl}$ at $\mathrm{pH} 7.6]$. After removal of nuclei by low-speed centrifugation, polysomes were pelleted at $130,000 \mathrm{~g}$ through a cushion of $30 \%$ sucrose in low salt buffer, resuspended in low salt buffer, and frozen. RSW was prepared as described previously, except the washing buffer contained $10 \%$ glycerol and $1.0 \mathrm{M} \mathrm{NaCl}$, rather than $0.5 \mathrm{M} \mathrm{KAc}$ (Ross et al. 1987).

Cell-free mRNA decay reactions containing $0.7 A_{260}$ units of polysomes $(-25 \mu \mathrm{g}$ of RNA) were performed as described previously (Ross et al. 1987). Competitor RNAs (see below) were added, where noted, at $1 \mu \mathrm{g}$ per $25 \mu \mathrm{g}$ of polysomal RNA. After incubation at $37^{\circ} \mathrm{C}$, total RNA was prepared by phenol extraction.

\section{Preparation of competitor RNAs}

Plasmid pSP6ClaRI or pSP6RICla (sense and antisense-oriented clones from the ClaI site in c-myc exon 3 to the EcoRI site in the 3 '-flanking region) was linearized and used in SP6 RNA polymerase transcription reactions with synthetic cap analog, as described previously (see Fig. 1; Peltz et al. 1987). DNA fragments subcloned from the coding region of human $\beta$-globin cDNA and from pGEM vector DNA were similarly transcribed to generate nonspecific competitor RNAs. The DNA template for RNA $d$ (Fig. 1) was synthesized by polymerase chain reaction (PCR) using a $5^{\prime}$ single-stranded DNA primer containing SP6 promoter sequences plus c-myc cDNA bases 1705-1722 and a 3 '-antisense primer from c-myc cDNA bases 1869-1886, the 1886 site being the third base of the last coding codon (amino acid 439). This DNA was either used directly in an SP6 transcription reaction or was subcloned into a vector lacking an SP6 promoter. In each experiment, vectors were cut at restriction enzyme sites such that the c-myc and nonspecific competitor RNAs were similar or identical in size.

\section{Analysis of polysome-associated mRNAs}

Northern blot analyses were performed as described by Church and Gilbert (1984) using Zeta-Probe membranes (Bio-Rad). The c-myc blotting probe indicated in Figure 1 was an Aval fragment that does not hybridize to competitors $a$ through $d$. Full-length cDNA probes were used for detecting c-myb, AP-4, $\gamma$-globin, and GAPDH mRNAs. All blotting probes were radiolabeled with ${ }^{32} \mathrm{P}$ by random priming (Feinberg and Vogelstein 1983). Equal RNA loading was determined in all experiments by stripping the blot and reprobing for a stable transcript such as $\gamma$-globin mRNA. RNase protection of c-myc mRNA, using a uniformly labeled $3^{\prime}$ probe (Fig. 1), and SI nuclease analyses of the $3^{\prime}$ regions of histone and $\gamma$-globin mRNAs were performed as described previously (Ross and Kobs 1986; Brewer and Ross 1988).

\section{Preparation of radiolabeled RNAs and gel-shift analysis}

Linearized templates (c-myc or $\beta$-globin cDNAs or pGEM vector DNA) were used in SP6 transcription reactions containing $\left[\alpha^{-32} \mathrm{P}\right]$ GTP to generate uncapped, radiolabeled RNAs. One nanogram of RNA was heated to $70^{\circ} \mathrm{C}$ for $5 \mathrm{~min}$, chilled on ice, and incubated with $0.4 A_{260}$ units of $\mathrm{K} 562$ polysomes for an equivalent amount of RSW protein eluted from polysomes in $1.0 \mathrm{M} \mathrm{NaCl}$ ) in $10 \mu \mathrm{l}$ containing $2 \mathrm{~mm} \mathrm{DTT}, 2 \mathrm{~mm}$ magnesium acetate, $0.4 \mathrm{~mm}$ spermine, $10 \%$ glycerol, $2.5 \mu \mathrm{g} / \mu \mathrm{l}$ of tRNA, and $10 \mathrm{mM}$ Tris- $\mathrm{HCl}(\mathrm{pH} 7.5)$. The reaction was incubated at $30^{\circ} \mathrm{C}$ for $10 \mathrm{~min}$ and was then treated with 1 unit of RNase T1 at $30^{\circ} \mathrm{C}$ for $10 \mathrm{~min}$. Heparin $(50 \mu \mathrm{g})$ was added to minimize nonspecific interactions. RNA-protein complexes were resolved from free RNA in a $6 \%$ nondenaturing polyacrylamide gel and visualized by autoradiography (Konarska and Sharp 1986). Where indicated, $4 A_{260}$ units of polysomes or an equivalent amount of RSW was pretreated with $10 \mu \mathrm{g}$ of trypsin for $30 \mathrm{~min}$ at $37^{\circ} \mathrm{C}$; 10 $\mu \mathrm{g}$ of soybean trypsin inhibitor was then added to inhibit further protease activity.

\section{$U V$-cross-linking analysis}

Mock mRNA decay reactions were carried out as described for the gel-shift analyses and were subsequently exposed for $5 \mathrm{~min}$ to $254 \mathrm{~nm}$ UV light at a distance of $3 \mathrm{~cm}$ (energy $=0.5 \mathrm{~J}$ ) in a Stratagene Stratalinker apparatus, to allow covalent bond formation between protein and radiolabeled RNA (Bohjanen et al. 1991). Reactions were then treated with $8 \mu \mathrm{g}$ of RNase A for 60 min at $37^{\circ} \mathrm{C}$, to digest non-cross-linked RNA. Radiolabeled proteins were analyzed by electrophoresis in a 10\% SDS-polyacrylamide gel under reducing conditions and were visualized by autoradiography.

\section{Construction of GlobMycGlob chimeric gene}

A 249-bp DNA fragment corresponding to the carboxy-terminal $83 \mathrm{c}-$ myc codons was prepared from c-myc cDNA by PCR. The $5^{\prime}$ and $3^{\prime}$ primers were 26-mer (5' -GCGAATTCCGAACACACAACGTCTTG) and 27-mer (5'-CTCGAATTCCGCACAAGAGTTCCGTAG), respectively. Each primer contained EcoRI restriction sites, which permitted insertion of this fragment into the EcoRI site of a human $\beta$-globin gene subcloned into pBS.KS M13 + (Stratagene). The orientation and sequence of the resulting GlobMycGlob clone were verified by $\mathrm{T} 7$ sequencing (Pharmacia). This clone was then inserted into the HindIII and Nsil sites of plasmid pB108, a eukaryotic expression vector containing the CMV immediate early promoter and $112 \mathrm{bp}$ of CMV 5'-untranslated sequence (Ghazal and Nelson 1991) plus the Escherichia coli hygromycin phosphotransferase gene (Gritz and Davies 1983). The CMV-GlobMycGlob gene expresses a 1006-nucleotide mRNA containing, in a $5^{\prime} \rightarrow 3^{\prime}$ order, 112 nucleotides of CMV exon 1, 13 nucleotides from a previously added HindIII linker, 419 nucleotides from the $\beta$-globin cap site to the EcoRI site (complete 5'-UTR plus codons for globin amino acids 1-121), 249 nucleotides from the terminal coding region of c-myc mRNA (amino acids 357-439), 6 nucleotides from the EcoRI linker, encoding Gln-Phe, and 207 nucleotides from the $\beta$-globin EcoRI site to the mRNA terminus (codons for globin amino acids $122-146$ plus complete $3^{\prime}$-UTR). This mRNA should utilize the normal $\beta$-globin translation initiation and termination signals, and the $c-m y c$ segment should be translated as well (see Fig. 6A). 


\section{HeLa cell culture and transfection}

Adherent HeLa cells were grown on 100 -mm dishes in $\alpha$-MEM plus $10 \%$ calf serum (GIBCO) supplemented with penicillin and streptomycin. Subconfluent cells $\left(\sim 5 \times 10^{6}\right.$ per dish) were transfected with $20 \mu \mathrm{g}$ of CMV-GlobMycGlob DNA, using lipofectin reagent (GIBCO BRL). A pool of cells was then selected using $400 \mu \mathrm{g} / \mathrm{ml}$ of hygromycin B (Boehringer Mannheim). Polysome isolation and in vitro mRNA decay reactions were performed as described for the K562 cells.

\section{Acknowledgments}

We are grateful to Peggy Farnham, Chris Sorenson, Robert McLaren, and Peter Leeds for comments on the manuscript, to Richard Spritz and Kay Lang for supplying the human $\beta$-globin cDNA clone, to Robert Eisenman for supplying the AP-4 probe, and to Bill Sugden and Tim Middleton for advice on the use of CMV expression vectors and for supplying $\mathrm{pB} 108$. This work was supported by grants CA23076, CA07175, and CA09230 from the National Institutes of Health. R.D.P. is supported by a fellowship from the Medical Research Council of Canada.

The publication costs of this article were defrayed in part by payment of page charges. This article must therefore be hereby marked "advertisement" in accordance with 18 USC section 1734 solely to indicate this fact.

\section{References}

Adam, S.A., T. Nakagawa, M.S. Swanson, T.K. Woodruff, and G. Dreyfuss. 1986. mRNA polyadenylate-binding protein: Gene isolation and sequencing and identification of a ribonucleoprotein consensus sequence. Mol. Cell. Biol. 6: 2932-2943.

Atkins, J. F., R.B. Weiss, and R.F. Gesteland. 1990. Ribosome gymnastics-Degree of difficulty 9.5, style 10.0. Cell 62: 413-423.

Bernstein, P., S.W. Peltz, and J. Ross. 1989. The poly $(A)$-poly $(A)-$ binding protein complex is a major determinant of mRNA stability in vitro. Mol. Cell. Biol. 9: 659-670.

Blackwell, T.K., L. Kretzner, E.M. Blackwood, R.N. Eisenman, and $\mathrm{H}$. Weintraub. 1990. Sequence-specific DNA binding by the c-myc protein. Science 250: 1149-1151.

Bohjanen, P.R., B. Petryniak, C.H. June, C.B. Thompson, and T. Lindsten. 1991. An inducible cytoplasmic factor (AU-B) binds selectively to AUUUA multimers in the $3^{\prime}$ untranslated region of lymphokine mRNA. Mol. Cell. Biol. 11: 3288-3295.

Bonnieu, A., M. Piechaczyk, L. Marty, M. Cuny, J.-M. Blanchard, P. Fort, and P. Jeanteur. 1988. Sequence determinants of c-myc mRNA turn-over: Influence of $3^{\prime}$ and 5' non-coding regions. Oncogene Res. 3: 155-166.

Bonnieu, A., P. Roux, L. Marty, P. Jeanteur, and M. Piechaczyk. 1990. AUUUA motifs are dispensable for rapid degradation of the mouse c-myc mRNA. Oncogene 5: 1585-1588.

Brewer, G. 1991. An A + U-rich element RNA-binding factor regulates c-myc mRNA stability in vitro. Mol. Cell. Biol. 11: 2460-2466.

Brewer, G. and J. Ross. 1988. Poly(A) shortening and degradation of the 3' AU-rich sequences of human c-myc mRNA in a cell-free system. Mol. Cell Biol. 8: 1697-1708.

- 1989. Regulation of c-myc mRNA stability in vitro by a labile destabilizer with an essential nucleic acid component. Mol. Cell. Biol. 9: 1996-2006.

Casey, J.L., D.M. Koeller, V.C. Ramin, R.D. Klausner, and J.B.
Harford. 1989. Iron regulation of transferrin receptor mRNA levels requires iron-responsive elements and a rapid turnover determinant in the $3^{\prime}$ untranslated region of the mRNA. $E M B O$ I. 8: 3693-3699.

Chen, C.Y., H. Opperman, and K. Hitzeman. 1984. Homologous versus heterologous gene expression in the yeast, Saccaromyces cerevisiae. Nucleic Acids Res. 12: 8951-8970.

Church, G. and W. Gilbert. 1984. Genomic sequencing. Proc. Natl. Acad. Sci. 81: 1991-1995.

Cleveland, D.W. and T.J. Yen. 1989. Multiple determinants of eukaryotic mRNA stability. New Biologist 1: 121-126.

Dani, C., J.M. Blanchard, M. Piechaczyk, S. El Sabouty, L. Marty, and P. Jeanteur. 1984. Extreme instability of myc mRNA in normal and transformed human cells. Proc. Natl. Acad. Sci. 81: 7046-7050.

Feinberg, A.P. and B. Vogelstein. 1983. A technique for radiolabeling DNA restriction endonuclease fragments to high specific activity. Anal. Biochem. 132: 6-13 /addendum 137: 266-267, 1984).

Ghazal, P. and J.A. Nelson. 1991. Enhancement of RNA polymerase II initiation complexes by a novel DNA control domain downstream from the capsite of the cytomegalovirus major immediate-early promoter. J. Virol. 65: 2299-2307.

Grange, T., C.M. de Sa, J. Oddos, and R. Pictet. 1987. Human mRNA polyadenylate binding protein: Evolutionary conservation of a nucleic acid binding motif. Nucleic Acids Res. 15: $4771-4787$.

Gritz, L. and J. Davies. 1983. Plasmid-encoded hygromycin B resistance: The sequence of the hygromycin B phosphotransferase gene and its expression in Escherichia coli and Saccharomyces cerevisiae. Gene 25: 179-188.

Hargrove, J.L. and F.H. Schmidt. 1989. The role of mRNA and protein stability in gene expression. FASEB I. 3: 2360-2370.

Harris, M.E., R. Bohni, M.H. Schneiderman, L. Ramamurthy, D. Schumperli, and W.F. Marzluff. 1991. Regulation of histone mRNA in the unperturbed cell cycle: Evidence suggesting control at two posttranscriptional steps. Mol. Cell. Biol. 11: $2416-2424$.

Hockema, A., R.A. Kastelein, M. Vasser, and H.A. de Boer. 1987. Codon replacement in the PGK1 gene of Saccharomyces cerevisiae: Experimental approach to study the role of biased codon usage in gene expression. Mol. Cell. Biol. 7:2914 2924.

Ito, K., K. Kashiwagi, S. Watanabe, T. Kameji, A. Hayashi, and K. Igarashi. 1990. Influence of the 5 '-untranslated region of ornithine decarboxylase mRNA and spermidine on ornithine decarboxylase synthesis. I. Biol. Chem. 265: 1303613041.

Jones, T.R. and M.D. Cole. 1987. Rapid cytoplasmic turnover of c-myc mRNA: Requirement of the 3' untranslated sequences. Mol. Cell. Biol. 7: 4513-4521.

Kanamori, H., N. Suzuki, H. Siomi, T. Nosaka, A. Sato, H. Sabe, M. Hatanaka, and T. Honjo. 1990. HTLV-1 p2 $7^{\text {rex }}$ stabilizes human interleukin receptor $\alpha$ chain mRNA. EMBO $J$. 9: $4161-4166$.

Kim, J., P.G. Klein, and J.E. Mullet. 1991. Ribosomes pause at specific sites during synthesis of membrane-bound chloroplast reaction center protein D1. I. Biol. Chem. 266: 1493114938.

Kindy, M.S. and G.E. Sonenshein. 1986. Regulation of oncogene expression in cultured aortic smooth muscle cells. Post-transcriptional control of c-myc mRNA. I. Biol. Chem. 261: 12865-12868.

Konarska, M.M. and P.A. Sharp. 1986. Electrophoretic separation of complexes involved in the splicing of precursors to mRNAs. Cell 46: 845-855. 
Kozak, M. 1991. Structural features in eukaryotic mRNAs that modulate the initiation of translation. I. Biol. Chem. 266: $19867-19870$.

Kuchka, M.R., M. Goldschmidt-Clermont, J. van Dillewijn, and J.-D. Rochaix. 1989. Mutation at the Chlamydomonas nuclear NAC2 locus specifically affects stability of the chloroplast $p s b D$ transcript encoding polypeptide D2 of PS II. Cell 58: 869-876.

Lachman, H.M., G. Cheng, and A.I. Skoultchi. 1986. Transfection of mouse erythroleukemia cells with myc sequences changes the rate of induced commitment to differentiate. Proc. Natl. Acad. Sci. 83: 6480-6484.

Laird-Offringa, I.A., P. Elfferich, and A.J. van der Eb. 1991. Rapid c-myc mRNA degradation does not require $(A+U)$-rich sequences or complete translation of the mRNA. Nucleic Acids Res. 19: 2387-2394.

Liang, H. and J.-P. Jost. 1991. An estrogen-dependent polysomal protein binds to the $5^{\prime}$ untranslated region of the chicken vitellogenin mRNA. Nucleic Acids Res. 19: 2289-2294.

Lindhout, P., L. Needleman, H. Van Tol, and V. Vloten-doting. 1985. Ribosomes are stalled during in vitro translation of alfalfa mosaic virus RNA I. Eur. J. Biochem. 152: 625-631.

Malter, J.S. 1989. Identification of an AUUUA-specific messenger RNA binding protein. Science 246: 664-666.

Malter, J.S. and Y. Hong. 1991. The adenosine-uridine binding factor recognizes the AU-rich elements of cytokine, lymphokine, and oncogene mRNAs. I. Biol. Chem. 266: 31723177.

Marzluff, W.F. and N.B. Pandey. 1988. Multiple regulatory steps control histone mRNA concentrations. Trends Biochem. Sci. 13: 49-52.

Mullner, E.W., B. Beupert, and L.C. Kuhn. 1989. A specific mRNA-binding factor regulates the iron-dependent stability of cytoplasmic transferrin receptor mRNA. Cell 58:373382.

Pei, R. and K. Calame. 1988. Differential stability of c-myc mRNAs in a cell-free system. Mol. Cell. Biol. 8: 2860-2868.

Peltz. S.W., G. Brewer, G. Kobs, and J. Ross. 1987. Substrate specificity of the exonuclease activity that degrades $\mathrm{H} 4$ histone mRNA. I. Biol. Chem. 262: 9382-9388.

Peltz, S.W., G. Brewer, P. Bernstein, P.A. Hart, and J. Ross. 1991. Regulation of mRNA turnover in eukaryotic cells. Crit. Rev. Eukaryotic Gene Expression 1: 99-126.

Picking, W.D., O.W. Odom, T. Tsalkova, I. Serdyuk, and B. Hardesty. 1991. The conformation of nascent polylysine and polyphenylalanine peptides on ribosomes. 1 . Biol. Chem. 266: 1534-1542.

Rahmsdorf, H.J., A. Schonthal, P. Angel, M. Litfin, U. Ruther, and P. Herrlich. 1987. Posttranscriptional regulation of c-fos mRNA expression. Nucleic Acids Res. 15: 1643-1659.

Ross, J. 1988. Messenger RNA turnover in eukaryotic cells. Mol. Biol. Med. 5: 1-14.

Ross, I. and G. Kobs. 1986. H4 histone mRNA decay in cell-free extracts initiates at or near the $3^{\prime}$ terminus and proceeds $3^{\prime}$ to 5'. I. Mol. Biol. 188: 579-593.

Ross, J., G. Kobs, G. Brewer, and S.W. Peltz. 1987. Properties of the exonuclease activity that degrades $\mathrm{H} 4$ histone mRNA. $J$. Biol. Chem. 262: 9374-9381.

Sachs, A.B., M.W. Bond, and R.D. Kornberg. 1986. A single gene from yeast for both nuclear and cytoplasmic polyadenylatebinding proteins: Domain structure and expression. Cell 45: $827-835$.

Schuler, G.D. and M.D. Cole. 1988. GM-CSF and oncogene mRNA stabilities are independently regulated in trans in a mouse monocytic tumor. Cell 55: 1115-1122.

Scornik, O.A. 1988. Role of idle ribosomes in the response of
Chinese hamster ovary cells to depletion of histidyl-tRNA. $J$. Cell. Physiol. 136: 125-132.

Shyu, A.-B., M.E. Greenberg, and J.G. Belasco. 1989. The c-fos transcript is targeted for rapid decay by two distinct mRNA degradation pathways. Genes \& Dev. 3: 60-72.

Shyu, A.-B., J.G. Belasco, and M.E. Greenberg. 1990. Two distinct destabilizing elements in the c-fos message trigger deadenylation as a first step in rapid mRNA decay. Genes \& Dev. 5: 221-231.

Siegel, V. and P. Walter. 1988. Functional dissection of the signal recognition particle. Trends Biochem. Sci. 13: 314-316.

Stern, D.B., H. Jones, and W. Gruissem. 1989. Function of plastid mRNA 3 ' inverted repeats. RNA stabilization and genespecific protein binding. J. Biol. Chem. 264: 18742-18750.

Swartwout, S.G. and A.J. Kinniburgh. 1989. c-myc RNA degradation in growing and differentiating cells: Possible alternate pathways. Mol. Cell. Biol. 9: 288-295.

Theodorakis, N.G., S.S. Banerii, and R.I. Morimoto. 1988. HSP70 mRNA translation in chicken reticulocytes is regulated at the level of elongation. I. Biol. Chem. 263: 1457914585.

Vakalopoulou, E., J. Schaack, and T. Shenk. 1991. A 32-kilodalton protein binds to AU-rich domains in the $3^{\prime}$ untranslated regions of rapidly degraded mRNAs. Mol. Cell. Biol. 11: 3355-3364.

Wager, R.E. and R.K. Assoian. 1990. A phorbol ester-regulated ribonuclease system controlling transforming growth factor $\beta 1$ gene expression in hematopoietic cells. Mol. Cell. Biol. 10: $5893-5990$.

Walter, P., R. Gilmore, and G. Blobel. 1984. Protein translocation across the endoplasmic reticulum. Cell 38: 5-8.

Weber, B., J. Horiguchi, R. Luebbers, M. Sherman, and D. Kufe. 1989. Posttranscriptinal stabilization of c-fms mRNA by a labile protein during human monocytic differentiation. Mol. Cell. Biol. 9: 769-775.

Wisdom, R. and W. Lec. 1990. Translation of c-myc mRNA is required for its post-transcriptional regulation during myogenesis. J. Biol. Chem. 265: 19015-19021.

- 1991. The protein-coding region of c-myc mRNA contains a sequence that specifies rapid mRNA turnover and induction by protein synthesis inhibitors. Genes \& Dev. 5: $232-243$.

Wolin, S.L. and P. Walter. 1988. Ribosome pausing and stacking during translation of a eukaryotic mRNA. EMBO /. 7: 35593569.

Yen, T.J., D.A. Gay, J.S. Pachter, and D.W. Cleveland. 1988a. Autoregulated changes in stability of polyribosome-bound $\beta$-tubulin mRNAs are specified by the first 13 translated nucleotides. Mol. Cell. Biol. 8: 1224-1235.

Yen, T.J., P.S. Machlin, and D.W. Cleveland. 1988b. Autoregulated instability of $\beta$-tubulin mRNAs by recognition of the nascent amino terminus of $\beta$-tubulin. Nature 334: 580-585. 


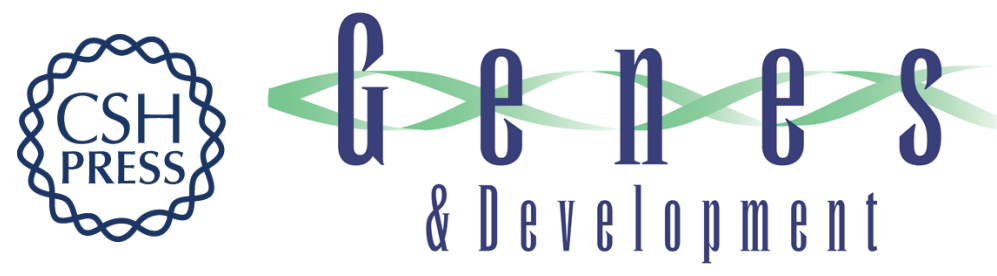

\section{Control of c-myc mRNA half-life in vitro by a protein capable of binding to a coding region stability determinant.}

P L Bernstein, D J Herrick, R D Prokipcak, et al.

Genes Dev. 1992, 6:

Access the most recent version at doi:10.1101/gad.6.4.642

References This article cites 64 articles, 33 of which can be accessed free at:

http://genesdev.cshlp.org/content/6/4/642.full.html\#ref-list-1

License

Email Alerting

Service

Receive free email alerts when new articles cite this article - sign up in the box at the top right corner of the article or click here.

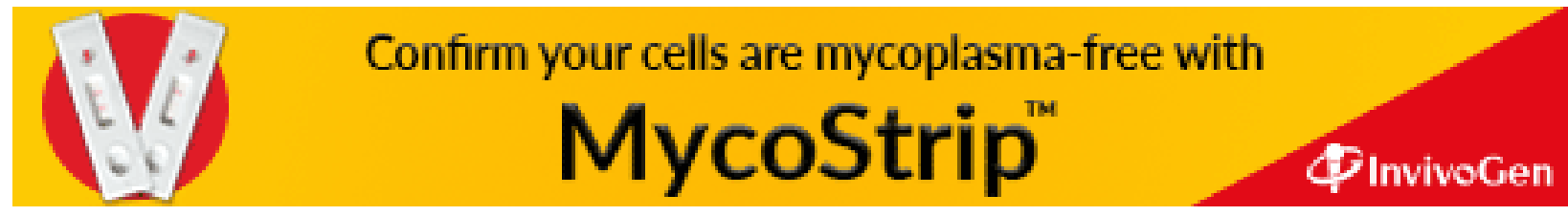

